\title{
Performing gender through stand-up comedy in Spanish
}

\author{
Leonor Ruiz-Gurillo \\ University of Alicante (Spain). GRIALE Research Group \\ Leonor.Ruiz@ua.es
}

\begin{abstract}
The aim of this paper is to examine Eva Hache's humorous gender-related monologues, broadcast in the show El Club de la Comedia [The Comedy Club] in Spain between 2012 and 2013. The corpus comprises 24 stand-up monologues, which have been analysed both quantitatively and qualitatively. The present paper offers a case study in three different ways. First, an analysis of different humorous sequences makes it possible to distinguish a representation of both feminine and masculine identities, as well as a confrontation between the two genders. In fact, Eva Hache's style supports the feminine identity and facilitates the teasing and mockery of men. Second, a polyphonic study of men as speakers (locutors) and utterers (Ducrot 1996) will serve to differentiate certain features of their identity from a discursive perspective. Finally, a detailed examination of humorous sequences shows how these performative sequences can prove useful to maintain hierarchy, to reinforce an in-group, i.e. a women's group, to solidify men's group boundaries, and even to subvert gender normativity (Bing 2004). As it will be demonstrated in our analysis, humorous markers and indicators play an important role in the construction of jab lines and the final punch line of these sequences. Furthermore, the results show that there are few strategies aimed at challenging the status quo in this corpus, although they illustrate an ongoing movement towards a feminist humour that has been almost non-existent in Spain so far.
\end{abstract}

Keywords: stand-up monologue, gender, female style, humorous sequence.

\section{Introduction}

Despite the fact that men and women show more similarities than differences when using humour (Crawford \& Gressley 1991: 228; Martin 2014: 146), those dissimilarities are fairly remarkable when humour becomes a mode of interpersonal communication. Indeed, it could be argued that gendered humorous discourse may either confirm a reinforcement of the status quo when it conveys certain gender-role attitudes and stereotypes, and, conversely, it may also create a site of feminist resistance (Crawford 1995, 2003). Consequently, humour is considered as a tool to construct and deconstruct masculinities and femininities (Crawford 
2003; Mushtaq 2017), since not only does it reinforce norms and stereotypes, but it also helps perform unconventional forms of gendered identities.

Since it has been claimed that humour can be used as a tool to perform gender (Chiaro \& Baccolini 2014), our paper seeks to analyse a type of performance humour: stand-up monologues. More precisely, our main purpose is to investigate the gender identity in Eva Hache's stand-up monologues through discourse analysis. This female comedian was the presenter of the TV show El Club de la Comedia (The Comedy Club, henceforth ECC) in three editions between 2011 and 2013, broadcast on La Sexta channel in Spain. ${ }^{1}$ Interestingly, Eva Hache was the first woman to present ECC, and despite often being the only woman in this stand-up comedy show, she used to stand out as one of the best monologists every night.

These comedy performances follow the model of stand-up comedy programs in the USA. So, their structure and rhetorical techniques (Greenbaum 1999; Rutter 2001), the typical situations described (Yus 2016: 159), and their negotiation of gendered aspects (Lockyer 2011) are similar to the original model. In the programme, Eva Hache used to introduce each guest comedian with a short monologue (four to five minutes long). In particular, the show had four guest comedians during the first and the second season in La Sexta channel, and five guests were invited during the third one. The present study thus takes as its overall reference 96 audiovisual monologues performed by Eva Hache in this introductory section of the show. ${ }^{2}$ However, our focus will be placed on a corpus of 23 stand-up monologues which were extracted from the total set because of their gender-based topics. In all of these samples, the comedian draws the audience's attention to situations that women and men encounter in daily life, and describes a wide range of male and female common behaviours and attitudes. It is also worth highlighting that one of the monologues included in our corpus belongs to the gala ceremony held on the occasion of La Sexta TV channel's fifth birthday (March 2011) (see Table 1). Furthermore, it needs to be pointed out that all the examples dealt with in this article were transcribed according to the Val.Es.Co. system. ${ }^{3}$

Table 1. Corpus of Eva Hache's gendered monologues.

\begin{tabular}{|c|c|c|}
\hline $\begin{array}{c}\text { Eva Hache's } \\
\text { monologues in ECC }\end{array}$ & $\begin{array}{c}\text { Eva Hache's } \\
\text { gendered monologues } \\
\text { in ECC }\end{array}$ & $\begin{array}{c}\text { Eva Hache's gendered } \\
\text { monologues in La Sexta's fifth } \\
\text { birthday Gala }\end{array}$ \\
\hline 96 & 23 & 1 \\
\hline \multicolumn{2}{|c|}{ TOTAL NUMBER } & $\mathbf{2 4}$ \\
\hline
\end{tabular}

Turning to the structure of this paper, the remainder of this work is organised as follows. To begin with, the corpus of 24 monologues allows us to propose a quantitative analysis (Section 2). The key topics of these monologues will be identified (Section 3): as hinted above, different topics concerning relationships appear in most of the monologues, with only a few of them covering work-related topics. Likewise, it will be argued that such gendered performances represent a humorous female style, i.e. Eva Hache's character supporting the feminine identity. Similarly, a portrayal of masculine identity as well as a confrontation of

\footnotetext{
${ }^{1}$ The Spanish show El Club de la Comedia has been broadcast in different television channels ever since 1999, emulating the American Stand-up Comedy. The present research work has focused on La Sexta's first, second, and third seasons, of which a total of 43 shows were aired.

${ }^{2}$ Some aspects of Eva Hache's monologues were previously analysed in Ruiz Gurillo (2013b, 2015b).

${ }^{3}$ The transcription keys used by Val.Es.Co. can be consulted at the website http://www.valesco.es/sistema.pdf, some of which are reproduced here: short pause $<0.5 \mathrm{sec}(/)$, average pause $[0.5,1] \mathrm{sec}(/ /)$, long pause $>1 \mathrm{sec}$ $(/ / /)$, continuation of turn $(=)$, overlaps [ ], falling intonation $(\downarrow)$, rising intonation $(\uparrow)$, suspended intonation $(\rightarrow)$, language uttered with lower intensity ${ }^{\circ}()^{\circ}$, no pause between interventions $(\S)$, direct speech (italic letters).
} 
both gender identities in different humorous sequences will be explored (Section 4). The sort of consequences which may derive from these gender-based sequences constitute our next focus of attention (Section 5). In fact, our interest in such sequences is twofold. We attempt to show how Eva Hache's stand-up monologues can help maintain not only the status quo and thus reinforce an in-group, namely women's group, but also sustain men's group boundaries, and even subvert the hierarchy. Finally, Section 6 will show a number of conclusions drawn from all the analysis, additionally discussing possible paths for further research.

\section{Constructing identities through stand-up monologues. The case of Eva Hache}

The constructionist perspective (Butler 1993: 3) focuses on communities of practices understood as groups that share terminology and linguistic norms and that are engaged in a mutual endeavour (Sunderland \& Litosseliti 2002: 31; Holmes \& Meyerhoff 2003; Rozek 2015: 27). Humorous styles and gender identity have been widely analysed in conversational humour (see among others Lampert \& Ervin-Tripp 1998; Hay 2000; Holmes et al. 2001; Holmes 2003; Kotthoff 2006). However, performance humour (Martin 2014: 123) has received less attention from pragmatics. Thus, monologues as a form of performance humour can serve as a tool to construct and deconstruct normative gender identities, i.e. either masculine or feminine, and it can also articulate alternative forms of sexuality (gay, lesbian, etc.). Doing gender through humour implies that monologues can maintain boundaries and stereotypes in accordance with the empowered masculine system, or, on the contrary, they could subvert some of the main clichés and topics related to sexuality, men, home, family, marriage, or religion. In fact, as stated above, subversive humour expresses an attitude of resistance towards some of the most common stereotypes and hackneyed clichés.

Following the proposal for jokes made by Bing (2004), Eva Hache's humorous style may have the following effects:

- It can reflect and reinforce hierarchy, that is, maintain the status quo.

- It can help subvert the status quo or try to challenge it.

- It can contribute to establishing an in-group: in other words, it creates a feeling of group solidarity.

- It can reinforce boundaries and stereotypes, or, to put it in another way, it can reinforce the out-group rather than the in-group.

Bearing in mind the aims of our study, we chose a corpus that includes 24 stand-up monologues - selected because gender is their main theme - performed by a woman. An initial quantitative analysis will focus on aspects such as themes, the type of gender representation (feminine identity, masculine identity, and confrontations of gender identities), and some of the effects of humorous gendered monologues (to maintain hierarchy, to reinforce stereotypes, to establish an in-group, and to subvert the hierarchy).

As regards the topics, the 24 humorous gender-based monologues revolve around the topic of work in $14.28 \%$ of the cases, while relationships take up the remaining $85.69 \%$. Eva Hache speaks about divorce, retirement, sports, and jealousy, among other things, but, interestingly, in $50 \%$ of the cases in which she speaks about intimate relationships, sex is explicitly mentioned in $42.84 \%$ of the total (see Figure 1 ). 


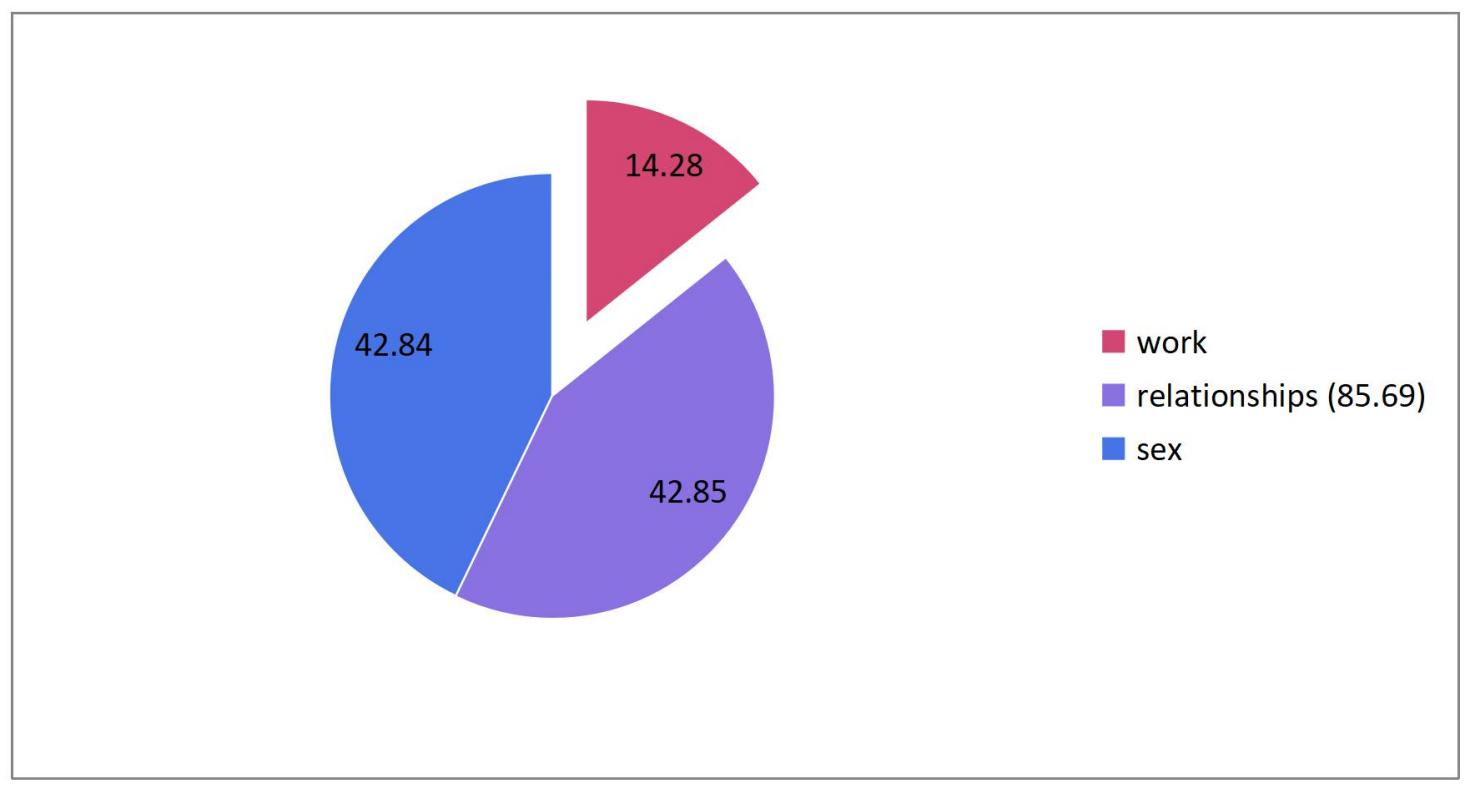

Figure 1. Topics of Eva Hache's humorous gendered monologues.

The unit of analysis is the humorous sequence, understood as a conversational storytelling structure in which the monologist develops a topic or sub-topic within a discontinuous intervention that is disrupted by the audience's laughter and applause (Val.Es.Co. 2014: 22-23; Pons 2014). ${ }^{4}$ This type of sequence finishes with a jab line or a punch line. Accordingly, a jab line appears as a humorous element integrated into the humorous plot that makes it easier to understand incongruity, whereas a punch line is also a humorous utterance closing the monologue (Attardo 2001: 82-83, 2008). In light of previous research (Ruiz-Gurillo 2012, 2013a, 2014), some elements help achieve the comedian's goals, mainly seeking to trigger laughter and applause, and consequently, to close the jab line or the punch line: humorous markers and indicators. Conceptually, a marker can be described as a linguistic element that contributes to infer humour. Examples may include: intonation, intensity of voice, pauses, or gestures. Furthermore, an indicator is a humorous element per se, as rightly explained in RuizGurillo (2014, 2015a). Humorous indicators, such as polysemy, ambiguity, phraseology, to quote but a few, play an important role in achieving the sequence goals. Eventually, depending on the feedback from the audience, the monologist may decide to add some humorous codas to trigger more laughter and applause. A total of 76 humorous sequences were identified in these 24 humorous gendered monologues.

The criterion for distinguishing these humorous sequences was the use of linguistic elements, such as first person singular or plural ( $I$ or we) when expressing her feminine identity, and the second person (you) when referring to the masculine identity. Interestingly, these subjects may appear combined in the same sequence when she deals with gender behaviour and attitudes. As Figure 2 shows, this type of sequence that reflects a confrontation or clash of gender identities appeared in 21 of the corpus samples (27.63\%). Moreover, as the corpus shows, Eva Hache represents the voice of feminine identity in 23 of 76 humorous sequences $(30.26 \%)$. In other occasions, the comedienne employs her humorous style to represent masculine identity, in particular, this happens in 32 out of 76 humorous sequences that make up our corpus (42.1\%) (see Figure 2).

\footnotetext{
${ }^{4}$ A similar concept was proposed by Attardo (2001: 83): a strand is a "(non-necessarily contiguous) sequence of (punch or jab) lines formally or thematically linked". Substrands together with central and peripheral strands were also proposed from a textual and isotopic perspective. Our concept of humorous sequence refers to the interaction with the audience on stage more adequately (see also Ruiz-Gurillo 2013b, 2014).
} 


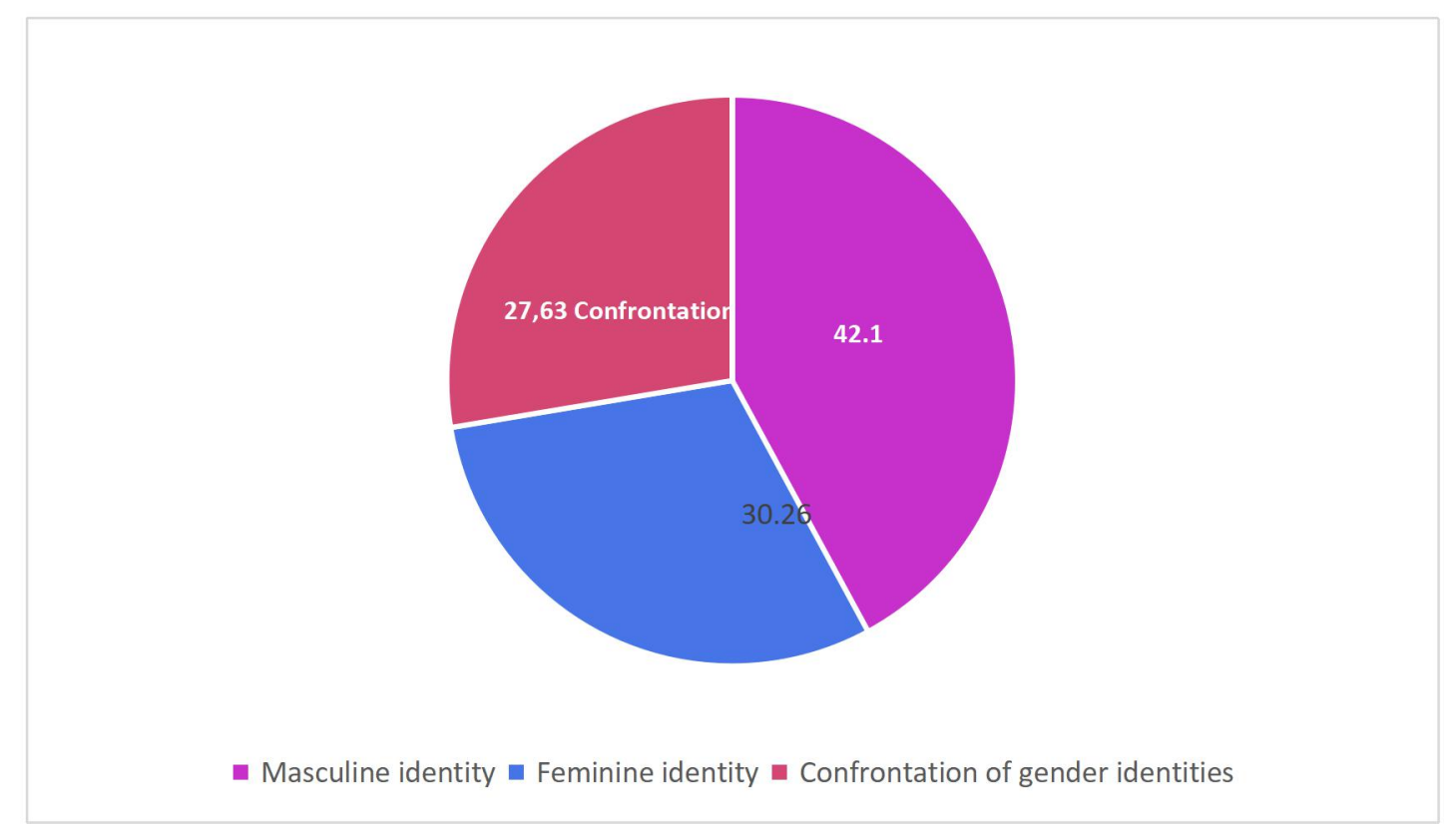

Figure 2. Humorous sequences and identity.

At the same time, a pragmatic analysis of the effects of humorous sequences performed in Eva Hache's monologues has been carried out. On the one hand, data show how Eva Hache's humorous gendered monologues maintain the hierarchy, that is, the status quo. Notably, she presents some male and female stereotypical features in 33 humorous sequences - from a total of 76 sequences - $(46.42 \%)$. In 11 out of 76 sequences $(14.47 \%)$ she shows solidarity with women and expresses her membership to this endogroup (van Dijk 1995). Furthermore, she sometimes confronts men and women (15 out of 76 sequences; 19.73\%), and subsequently succeeds in reinforcing several stereotypes. Notwithstanding this effect, the comedienne also gets to subvert the status quo in 17 of the 76 sequences examined (22.36\%). Accordingly, this happens when she pokes fun at men, when she depicts an intersectional category, namely gay, lesbian, bisexual, etc. (Day 2015), and when she presents a non-stereotypical representation of sexes (see Figure 3).



Figure 3. Effects of humorous sequences. 


\section{Topics in Eva Hache's monologues}

Following with the analysis of the most important topics in the monologues, the quantitative corpus shows that 22 out of these 24 monologues $(85.69 \%)$ deal with romantic relationships. The most frequent subtopics are divorce, retirement, sports, jealousy, and sex. Interestingly, 11 out of these 22 monologues focus on sexual intercourse (42.84\%). In contrast, only two out of the 24 humorous gendered monologues by Eva Hache under study focus on the topic of work (14.28\%). Work-based topics actually stress gender stereotypes as well. Eva Hache appears as the presenter of El Club de la Comedia and comments on the difficulties faced by women working on television (1):

(1)

Eva Hache: hola ¿qué tal? muy buenas noches/ dicen que para trabajar en La Sexta hace falta estar buena

Público: RISAS

Eva Hache: es mentira/ de hecho es todo lo contrario/ si trabajas en La Sexta te pones cañón (Gala La Sexta, La Sexta, 27 de marzo de 2011).

Eva Hache: Hi, how are you? good evening/ they say you must be hot to work for La Sexta Audience: LAUGHTER

Eva Hache: that's a lie/ in fact/ it's just the opposite/ if you work for La Sexta/ you become gorgeous

In example (1), the humorous sequence starts with the indicator to be hot. Eva Hache creates incongruity with the double entendre ("to be attractive" and "to put on weight"). After audience's laughter, the utterance that's a lie acts as a humorous marker of non-bona fide communication (Raskin 1985; Shilikhina 2017) that helps to complete the jab line you become gorgeous.

\section{Identities in stand-up monologues}

As the quantitative analysis shows, the most salient gender identities reflected in our corpus are the heteronormative ones: feminine and masculine, which can be depicted either separately or in opposition to one another. Humorous markers and indicators will be addressed as linguistic elements that help shape jab lines and the final punch line of the monologue. This humorous language is what supports her comic authority on stage, that is, her stage persona (Greenbaum 1999). It is worth noting that, although Eva Hache's monologues were written by an anonymous scriptwriter, her character on the TV set represents a feminine style. Indeed, Eva Hache employs her humorous discursive style (Kotthoff 2006) to reproduce a feminine identity, of which she is a part (4.1.), a masculine identity (4.2.), and even the confrontation between the two (4.3.).

\subsection{The feminine identity}

Eva Hache as a character embodies a feminine identity voice in 23 out of the 76 humorous sequences $(30.26 \%)$ under study. Her humorous style reproduces some of the most common stereotypes attached to women and their behaviour. Consequently, she shows the image of a modern, young, pretty, hard-working, autonomous, homey, and partnered woman. As pointed out above, her favourite topics are sex, couples' intimacies, and domestic conflicts.

Eva Hache represents a modern woman with social attributes such as intelligence, friendliness, and attractiveness. Thus, she constructs her identity as an intelligent woman: 
(2)

Eva Hache: pues fíjate a mí como mujer de cierta notoriedad $\downarrow$ simpática/ divertida/ [inteligente=]

Público: [iguapa!]

Eva Hache: =atractiva

Público: RISAS

Eva Hache: y a la que no se le sube todo esto a la cabeza pese a haber sacado un 7'6 en selectividad $\uparrow$

Público: RISAS

Eva Hache: me preguntan mucho/mucho (ECC, La Sexta, 4 de septiembre de 2011).

Eva Hache: well/ mind you/ me as a woman of a certain notoriety $\downarrow$ nice/ amusing / [intelligent=]

Audience: [pretty!]

Eva Hache: =good-looking

Audience: LAUGHTER

Eva Hache: and who/ all this has not gone to my head/ despite getting a 7.6 out of 10 on the university entrance examination $\uparrow$

Audience: LAUGHTER

Eva Hache: I am very/very often asked

\subsection{The masculine identity}

On the other hand, Eva Hache's feminine identity defies and confronts her male counterparts' identity in 32 out of the 76 humorous sequences (42.1\%) included in the corpus. The powerful female position poses an image of men as an inferior human being, and, in fact, it could be argued that men are depicted as a stigmatised gender. This representation entails discursive consequences: as the corpus shows, a man does not have a voice of his own, since he is frequently represented as an utterer, whereas he is hardly ever depicted as a speaker (locutor) (Ducrot 1996). ${ }^{5}$ Thus, a man as an utterer may be easily targeted.

Sometimes a man is represented as a speaker (locutor), which means that he is responsible for his enunciation (for his opinions, beliefs, and acts) and he manifests himself as a character. As it will be illustrated below, a man's behaviour is obviously the opposite of Eva Hache's, whose position expresses a female alignment. This powerful female position onstage, acting as the main speaker, also entails mockery and teasing of men.

\subsubsection{A man as an utterer}

Examples where a man is depicted as an utterer show stigmatised and targeted males. The female style of the humourist objectifies him. For instance, a handsome man with a perfect body is compared with a dish of haute cuisine:

(3)

Eva Hache: tú piensas este tío es tan guapo que solo puede ser modelo o hijo de cir- de cirujano plástico/ ¡qué belleza!/ te pide pa saliir muy bien pedío ¿sabes?

Público: RISAS

Eva Hache: todo empieza a ir de maravilla $\downarrow$ todo es perfecto/ el tiempo que pasas con él te pasa muy muy rápido/ y luego te acuestas con él y lo mismo $\downarrow$ te pasa muy muy rápido

Público: RISAS

\footnotetext{
${ }^{5}$ Following the Bakhtinian classification of voices, Ducrot's (1996) polyphony theory suggests that three roles may be distinguished: the talking subject who refers to the person uttering the words; the speaker (locutor) to whom these words are attributed, and who is responsible of the said; and the utterer who depicts a voice but is not responsible for the sentence. Obviously, these three figures are equal in most discourses. However, direct speech represents a speaker, whereas indirect speech represents an utterer.
} 
Eva Hache: son un pocoo hombres plato de alta cocina ¿mm? los ves $\uparrow$ se te hace la boca agua $\uparrow$ te acuestas con ellos y te quedas como estabas

Público: RISAS

Eva Hache: es un poco triste/ no $\downarrow$ no aplaudas porque es un drama

Público: RISAS Y APLAUSOS (Gala La Sexta, LaSexta, 27 de marzo de 2011).

Eva Hache: you think this guy is so handsome that he can only be a model or the son of a plastic sur-surgeon/ what a beauty/ he asks you for a date just as he should $\downarrow$ you know?

Audience: LAUGHTER

Eva Hache: it all starts going wonderfully $\downarrow$ everything is perfect/ the time you spend with him, you have the impression that it goes by so so fast/ and then you go to bed with him and the same $\downarrow$ you have the impression that everything finishes so so fast

Audience: LAUGHTER

Eva Hache: they're a bit haute-cuisine-dish men $\downarrow$ mm? you look at them $\uparrow$ and they make your mouth water $\uparrow$ you go to bed with them and you feel as if nothing had happened

Audience: LAUGHTER

Eva Hache: it's a bit sad/ no $\downarrow$ don't clap because it's a drama

Audience: LAUGHTER AND APPLAUSE

Males appear as utterers in example (3), which is why their voices are confused with Eva Hache's voice. Only Eva Hache, as a speaker-locutor, uses direct speech ${ }^{6}$ (you think this guy is so handsome that he can only be a model or the son of a plastic sur-surgeon). In this case, the most important indicator of the jab line is the structure haute-cuisine-dish men.

Even though topics about the household and relationships have been proved to be the most salient in the monologues examined, Eva Hache also refers to the work environment in some of her performances. The comedienne compares the behaviour of female and male bosses. More specifically, she explains the meaning of complicity for a man as well as for a woman:

(4)

Eva Hache: prefiero jefa/ sí porque hay más complicidad/ ojo $\downarrow$ que no quiere decir que con un jefe no pueda haber complicidad ¡claro que puede haber!

Público: RISAS

Eva Hache: bastante complicidad

Público: RISAS

Eva Hache: incluso mucha

Público: RISAS

Eva Hache: muchísima

Público: RISAS

Eva Hache: demasiada ${ }^{7}$

Público: RISAS

Eva Hache: sí $\downarrow$ porque para algunos hombres tener complicidad significa dos cosas/ acostarse con ella/ o cometer un delito juntos y acostarse con ella

Público: RISAS

Eva Hache: sí

Público: APLAUSOS (ECC, La Sexta, 30 de octubre de 2011).

\footnotetext{
${ }^{6}$ Direct speech is marked with italic letters in transcribed text, according to Val.Es.Co. proposal (Val.Es.Co. 2002).

${ }^{7}$ She nods.
} 
Eva Hache: I prefer female boss/ yes $\downarrow$ because there is more complicity/ mind you $\downarrow$ this does not mean that there cannot be complicity with a male boss/ there can be indeed!

Audience: LAUGHTER

Eva Hache: some complicity

Audience: LAUGHTER

Eva Hache: even a lot

Audience: LAUGHTER

Eva Hache: a hell of a lot

Audience: LAUGHTER

Eva Hache: too much

Audience: LAUGHTER

Eva Hache: yes $\downarrow$ because for some men/ complicity means two things/ going to bed with her/ or commit an offence together and go to bed with her

Audience: LAUGHTER

Eva Hache: yes

Público: APPLAUSE

The use of the polysemic expression to have complicity acts as an indicator to depict male behaviour. Moreover, the comedienne explains how different the meaning of the collocation to commit an offence is for men and women, and this polysemic comparison also acts as an indicator. Finally, the resolution of the incongruity entails a brilliant punch line, which provokes laughter and uproarious applause from the audience. Note that, as regards laughter and applauses, they were preceded, in most cases, by several codas based on a scale of quantifiers (some complicity, even a lot, hell a lot, too much) that prepared the audience to take the jab line substantiated on the polysemy of to have complicity.

\subsubsection{A man as a speaker (locutor)}

Even though most sequences of male representation show him as an utterer, a man as a speaker (locutor) may be documented in our corpus as well. In these cases, he is responsible for his enunciation, since he has his own voice (Ducrot 1996). In fact, Eva Hache represents this male voice using direct speech and occasionally a falsetto voice. This discursive role of men fosters mockery and parody and finally triggers laughter and applause. Example (5) shows a man obsessed with old T-shirts:

(5)

Eva Hache: pero no $\downarrow$ a ver $\downarrow$ a ver ¿cómo iba yo a saber que con el trapo que estabaa yo ahíi frenéticamente limpiando era su camiseta favorita?

Público: RISAS

Eva Hache: chico yo qué sé $\downarrow$ si la he encontrao ahí en un cajón hace mil años que no te la pones jay que era mi mejor camisetaa! ${ }^{8}$ ah $\downarrow$ es verdad que era buena/ ahí le tengo que dar la razón/ no veas cómo me ha dejao los cristales/ me ha dejao los cristales sin una pelusa Público: RISAS (ECC, La Sexta, 8 de enero de 2012).

Eva Hache: but no $\downarrow$ I mean $\downarrow$ I mean, how was I supposed to know that the rag that I waas there cleaning like crazy (with) was his favourite T-shirt?

Audience: LAUGHTER

Eva Hache: man/ I don't know $\downarrow$ I just found it in a drawer $\downarrow$ you haven’t worn it for ages $\rightarrow$ oh deeear, it was my best teee-shirt! ah! it is true that it was good/ he was right about that/ just look at how I left the glasses with it/ it's left my glasses without a single ball of fluff Audience: LAUGHTER

\footnotetext{
${ }^{8}$ The man's voice is represented sarcastically.
} 
Within the work context, a man is also depicted as a speaker (locutor). In example (6), Eva Hache compares the male and female behaviour as bosses:

(6)

Eva Hache: que es verdad que entre jefa y jefe hay otras diferencias $\downarrow$ como por ejemplo que los jefes dan ÓRDENES y las jefas dan sugerencias

Público: RISAS

Eva Hache: ¿qué es una sugerencia? gracias por la pregunta $\downarrow$ una orden $\uparrow /$ pero utilizandoo eevoz suave $\downarrow$ diminutivos/ y acabando con ¿vale, chicos?

Público: RISAS

Eva Hache: sí $\downarrow$ sí $\downarrow$ donde un tío diría ee- hoy no sale nadie hasta las diez $\uparrow$ una tía diría ${ }^{9} m m$ igual hoy salimos un poquito más tardecito ¿vale, chicos?

Público: RISAS (ECC, La Sexta, 4 de septiembre de 2011).

Eva Hache: it is true that other differences exist between a female boss and a male boss $\downarrow$ such as/ for instance/ that male bosses give ORDERS and female bosses give suggestions

Audience: LAUGHTER

Eva Hache: what is a suggestion? thanks for the question $\downarrow$ an order $\uparrow /$ but using er- a soft voice $\downarrow$ diminutives/ and finishing with okay, boys?

Audience: LAUGHTER

Eva Hache: yes $\downarrow$ yes $\downarrow$ where a guy would say er- nobody will leave until ten today $\uparrow$ a girl would say ${ }^{10} \mathrm{~mm}$ we might leave a little bit more latish today, okay, boys?

Audience: LAUGHTER

Note that the woman is depicted with a falsetto voice and melodic autonomy, whereas the man's voice becomes integrated into the melody curve and has no pitch changes. Seeking to achieve the humorous goals, the direct speech of the boss speaker (locutor) relies upon the suffix -ito (un poquito más tardecito [a little bit more latish]) and conversational discourse markers (okay, boys?). Therefore, although both genders are parodied, man is always the target, therefore it implies a greater degree of mockery towards him.

\subsection{Confrontation of gender identities}

As the corpus shows, confrontation between gender identities is represented in 21 out of 76 humorous sequences $(27.63 \%)$. In these sequences, one can also appreciate a parody focused on masculine identity. Indeed, the confrontation of gender identities appears as a gender conflict where a woman is identified with joy and fun, while a man behaves in a boring and monotonous manner. This confrontation is taken to the extreme in the following monologue about the types of underwear. Example (7) comments on the issue of feminine lingerie:

(7)

Eva Hache: vamos a hablar de ropa interior (RISAS)

Público: RISAS

Eva Hache: la ropa interior ¿sabéis? ese universo de seda $\downarrow$ de encajee $\downarrow$ ese mundo suave bonito inútil (RISAS)

Público: RISAS

Eva Hache: bueno $\downarrow$ sé de lo que hablo porque la lencería $\downarrow$ the lencery ee- se llama ropa interior y no se debería llamar ropa interior/ se debería llamar ropa exterior ¿por qué? porque es para enseñarla

Público: RISAS

\footnotetext{
${ }^{9}$ With a falsetto voice.

${ }^{10}$ With a falsetto voice.
} 
Eva Hache: y si no a ver ¿por qué nos hemos dejao de poner esa braga de algodón blanca de toda la vida? $\uparrow$

Público: RISAS

Eva Hache: ¿que era cálida y abrigada?

Público: RISAS

Eva Hache: y en cambio nos estamos poniendo esa ropa $\uparrow /$ esa ropa monísima $\uparrow$ pero que se escurre por toas partes/ que insiste en meterse en agujeros ocultos de nuestros cuerpos/ cuestan el triple y tapan la mitad

Público: RISAS

Eva Hache: a mí personalmente me cuesta ponerme ropaa que tiene el único objetivo de que me la quiten

Público: RISAS

Eva Hache: desde aquí lo digo/ tengo ropa interior que debería llamarse interna

Público: RISAS

Eva Hache: no se ve ni cuando la enseño

Público: RISAS (ECC, La Sexta, 30 de octubre de 2011).

(7)

Eva Hache: let's talk about underwear (LAUGHTER)

Audience: LAUGHTER

Eva Hache: underwear $\downarrow$ you know? that universe of silk $\downarrow$ of lace $\downarrow$ that soft beautiful useless world (LAUGHTER)

Audience: LAUGHTER

Eva Hache: well $\downarrow$ I know what I'm talking about because lingerie $\downarrow$ the lencery ee??- is called underwear and should not be called underwear/ it should be called upperwear, why? because it is meant to be shown

Audience: LAUGHTER

Eva Hache: why else have we stopped wearing those traditional white cotton panties?

Audience: LAUGHTER

Eva Hache: which were hot and warm?

Audience: LAUGHTER

Eva Hache: and/ instead $\downarrow$ we are wearing those clothes $\uparrow /$ those really cute clothes $\uparrow$ but which slips away ev'rywhere/ which keep getting into hidden holes of our bodies/ they cost three times as much and they cover only half

Audience: LAUGHTER

Eva Hache: I personally find it hard to put on clothes which are exclusively for someone to strip me off it

Audience: LAUGHTER

Eva Hache: I'm saying it from here/ I have some underwear which should be called "internal"

Audience: LAUGHTER

Eva Hache: it cannot be seen/ not even when I show it

Audience: LAUGHTER

This humorous sequence is based on the indicators ropa interior [underwear] and ropa interna ["internal wear"]. The first one is a syntagmatic compound that is remotivated as upperwear. She also plays with the word lingerie and the invented word lencery. This jab line triggers laughter from the audience. ${ }^{11}$ below:

On the other hand, Eva Hache confronts masculine and feminine underwear in example (8)

${ }^{11}$ Unfortunately, this jab line works very well in Spanish, but not in English. 
(8)

Eva Hache: es una pen- una pen- una penita lo vuestro chicos porque en cuanto a ropa interior no tenéis opciones/ tenéis el modelo corto o sea sliP/ el modelo largo bóxer// ya está/ buen- o no llevar

Público: RISAS

Eva Hache: son tres opciones $\downarrow$ higiénicas dos

Público: RISAS

Eva Hache: y que apetezca ver una

Público: RISAS

Eva Hache: las mujeres en cambio no/ las mujeres tenemos un PARAÍ́SO de la elección $\downarrow$ abres un cajón de ropa interior y ¡halaa! y ¡vengaa! hasta demasiadas diría yo/ está la braga $\downarrow$ la braga tanga $\downarrow$ la taanga de hilo $\downarrow$ la tanga vista $\downarrow$ la braga baja de caderaa $\downarrow$ el culotte $\downarrow$ la braga clásica $\downarrow$ la braga con puntilla $\downarrow$ la braga sin puntilla $\downarrow$ el short $\downarrow$ una mujer abre un cajón de la ropa interior y se queda bizca $\downarrow$ es como aaa ¿qué me va a deparar el destino?

Público: APLAUSOS (ECC, La Sexta, 30 de octubre de 2011).

(8)

Eva Hache: such a sh- a sh- a shame for you, boys, because when it comes to underwear, you have no options/ you have the short type, that is sliP/ the long one boxer// that's it/ well- or not wearing any

Audience: LAUGHTER

Eva Hache: it's three options $\downarrow$ two of them hygienic

Audience: LAUGHTER

Eva Hache: and one that you fancy looking at

Audience: LAUGHTER

Eva Hache: it's different for women $\downarrow$ though/ we (women) have a PARADISE of choice $\downarrow$ you open an underwear drawer and wow! and geez! actually too many $\downarrow$ I would say/ there's the panties $\downarrow$ tanga panties $\downarrow$ g-strings $\downarrow$ visible tanga under leggings $\downarrow$ low-hip panties $\downarrow$ culottes $\downarrow$ classic panties $\downarrow$ panties with lace $\downarrow$ panties without lace $\downarrow$ shorts $\downarrow$ a woman opens an underwear drawer and she goes cross-eyed $\downarrow$ it's like aaa $\downarrow$ what will fate have in store for me?

Audience: LAUGHTER

Some indicators such as the metaphor paradise of choice and the enumeration of types of panties, in contrast to the small variety of men's underwear, help achieve the humorous effect of the sequence. Also note that the intensity of voice in paradise, marked with capital letters in the transcription, makes it easier to understand this jab line.

Another confrontational topic is that of a woman's handbag as opposed to a man's wallet. Eva Hache mocks men who cannot understand why women carry such a bulky handbag. Additionally, she counterattacks by making fun of men's wallets:

(9)

Eva Hache: la culpa es vuestra/ porque vais provocando

Público: RISAS

Eva Hache ${ }^{12}$ : cuántas veces nos habremos escuchao mira cómo llevas el bolso $\downarrow$ mira cómo llevas el bolso $\downarrow$ cuántas cosas llevas ahi en el bolso $\downarrow$ pa qué te hacen falta tantas cosas/ Mary Poppins Público: RISAS Y APLAUSOS

Eva Hache: ¿habéis visto cómoo lleváis vosotros la cartera?

Público: RISAS

Eva Hache: ¿eh? que te cruzas con un tío por la calle pa mirarlee eel- los andares $\uparrow$

Público: RISAS

Eva Hache: y es que no falla ves dos balones de playa

12 She nods. 
Público: RISAS

Eva Hache: pero uno hinchao y el otro no

Público: RISAS Y APLAUSOS (ECC, La Sexta, 25 de septiembre de 2011).

Eva Hache: it's your fault/ because you are provocative

Audience: LAUGHTER

Eva Hache: we have heaard so many times just look at your handbag $\downarrow$ just look at your handbag $\downarrow$ you carry so many things there in the handbag $\downarrow$ wha' do you need so many things for/ Mary Poppins

Audience: LAUGHTER AND APPLAUSE

Eva Hache: have you seen whaat your wallet looks like?

Audience: LAUGHTER

Eva Hache: eh? you pass a guy in the street to loook at the- the way he walks

Audience: LAUGHTER

Eva Hache: sure thing $\downarrow$ you see two beach balls

Audience: LAUGHTER

Eva Hache: though one inflated and the other not

Audience: LAUGHTER AND APPLAUSE

Despite being depicted with his own voice using direct style as a speaker (locutor) in example (11), the man is not safe from mockery. The comparison between men's pockets and two beach balls acts as the main humorous indicator in this jab line.

Summing up, humour in Eva Hache's monologues acts as an excellent tool to highlight some differences between women and men, to make fun of common situations, to laugh at men and even to show the way gender identities can clash in humorous sequences.

\section{Effects of humorous sequences}

As the quantitative analysis revealed, Eva Hache's gendered monologues focus on hierarchy maintenance (43.42\% of humorous sequences), followed by its subversion $(22.36 \%)$, the reinforcement of stereotypes (19.73\%) and the establishment of women's in-group (14.47\%). These categories, understood as a dynamic construction of female style, serve as the axis of humorous effects, which will be explained below.

\subsection{Hierarchy maintenance}

As seen above, ECC monologues do not convey a subversive type of humour against the status quo. Each monologue generally starts with a shared common ground and, consequently, most of the sequences help maintain existing hierarchies. In these cases, Eva Hache speaks about female and male beliefs and stereotypes. In example (10), she refers to the stereotype of retirement and its consequences on couples:

(10)

Eva Hache: que sí que sí que sí una cosita os voy a decir/ por mucho amor por mucho respeto por mucha confianza que haya en una pareja siempre se llega a un momento MUY difícil de superar// al loro ¿eh?/ la jubilación

Público: RISAS

Eva Hache: hasta entonces la pareja van bien- va bien porque solamente se piensa A CORTO PLAZO/ se dice ¿qué hacemos esta tarde? ¿qué hacemos con lo que ha sobrao del cocido?

Público: RISAS

Eva Hache: ¿qué hacemos con los tickets estos de descuento para el circo? pues se hace lo que se ha hecho toa la vida $\downarrow$ tirarlo a la basura 
Público: RISAS

Eva Hache: pero la jubilación lo cambia todo/ lo cambia TODO (ECC, La Sexta, 4 de diciembre de 2011).

Eva Hache: yes $\downarrow$ yes $\downarrow$ yes $\downarrow$ there's a little I must tell you about/ no matter how much love $\downarrow$ how much trust there is in a couple $\downarrow$ they always reach a moment that is VERY hard to overcome// check it out $\downarrow$ right?/ retirement

Audience: LAUGHTER

Eva Hache: the couple does well until then- does well because they think of THE SHORT TERM/ what they say is/ what are we doing this evening? what are we going to do with the leftovers of the stew?

Audience: LAUGHTER

Eva Hache: what shall we do with those discount vouchers for the circus? well $\downarrow$ they do what has always been done $\downarrow$ throw it to the rubbish bin

Audience: LAUGHTER

Eva Hache: but retirement changes everything/ changes EVERYTHING

It is worth highlighting that this sequence takes place when Eva Hache begins her monologue which, despite being based on maintaining the status quo upon retirement, deals with some sequences differently, as in this case.

\subsection{Establishment of women's in-group}

After having established the common grounds, she goes a step forward and backs up female identities. In general, she represents women's voice, and hence her speech helps establish a feeling of female group solidarity. She shares her experiences and expects sympathy and women's laughter as a response. As pointed out by Hay (2000), women use humour to create and maintain solidarity more often than men. In fact, this reinforcement of female endogroup membership (van Dijk 1995) stands out as one of the most applauded elements in the performance. This fact shows that Eva Hache's strategy to create and maintain solidarity, mainly with the female audience, attained its goals, i.e. to create an in-group feeling, and to cause laughter and applause.

Some examples illustrate the success achieved with such sequences. In example (11), Eva Hache explains that women carry plenty of useful things in their handbags, compared to men:

(11)

Eva Hache: además que por lo menos nosotras llevamos el bolso lleno sí $\downarrow$ pero de cosas útiles $\downarrow$ cosas útiles/pañuelos de papel $\downarrow$ tiritas $\downarrow$ bolígrafos $\downarrow$ maquillaje $\downarrow$ pan de oro $\downarrow$ betún de Judea Público: RISAS Y APLAUSOS

Eva Hache: pero vosotros ¿qué? ¿qué lleváis ahí? (ECC, La Sexta, 25 de septiembre de 2011).

Eva Hache: besides $\downarrow$ at least we carry our handbag full/ yes $\downarrow$ but full of useful things $\downarrow$ useful things/ paper tissues $\downarrow$ band-aids $\downarrow$ pens $\downarrow$ make-up $\downarrow$ gold leaf $\downarrow$ Judea bitumen

Audience: LAUGHTER AND APPLAUSE

Eva Hache: and/ what about you? what do you carry in there?

The jab line, composed by the pseudo-comprehensive element ${ }^{13}$ useful things, which encompasses paper tissues, band-aids, pens, make-up, gold leaf and Judea bitumen achieves the main goal of triggering laughter and applause. It needs to be stressed that the contextual semantic class encompasses not only usual things, such as paper tissues, band-aids, pens, and

${ }^{13}$ Pseudo-comprehensive elements imply the creation of a semantic class comprising various integrated elements which do not exhaust it, but are reinterpreted as if they did (Timofeeva 2012). 
make-up, but also strange things for a handbag, such as gold leaf and Judea bitumen. The incongruity between these arouses laughter and mirth amongst the audience.

\subsection{Stereotype reinforcement}

As stated above, assuming a sense of belonging to a women's group leads to reinforce boundaries. More precisely, the adaptability of humour (Ruiz-Gurillo 2016) to an in-group is what makes the comedienne select scripts where women are awesome and clever, as opposed to the boring and stupid men. Similarly, the variability of humour also becomes evident through a variety of personal pronouns. The monologist deliberately uses we to refer to women as a whole, and you or they to refer to men. Consequently, differences between us and you or them may be interpreted as a type of gender confrontation which ends up reinforcing stereotypes. Gender confrontation in example (12) relies upon parodying men. Eva Hache speaks about a friend who has asked her partner for more security:

Eva Hache: estoy un pelín preocupada porque tengo una- una amiga que ha discutido con su novioo ¡bah! por una tontería/ resulta que ella le dijo que había llegao un momento de su vida en que lo que necesitaba era alguien que le diera seguridad

Público: RISAS

Eva Hache: y éel/ pues le ha puesto un guardia jurao y un perro

Público: RISAS

Eva Hache: no se refería a eso (ECC, La Sexta, 22 de enero de 2012).

Eva Hache: I'm a little bit worried because I have a- a friend who has argued with her boyfriend, huh! for a silly thing/ it turns out that she told him that she had reached a moment of her life in which what she needed was someone who gave her security

Audience: LAUGHTER

Eva Hache: and hee/ well $\downarrow$ he has hired a private security guard and has bought a dog for her

Audience: LAUGHTER

Eva Hache: that's not what she meant

The polysemy of security, interpreted as "emotional security in the couple" and "physical security", constitutes the grounds for this jab line. The pause after the sentence "what she needed was someone who gave her security" triggers laughter, which increases after the resolution of the incongruity. Furthermore, this sequence makes it easier to maintain the stereotype based on men who do not need emotional security with their partner and women who prefer a long-term relationship.

\subsection{Subversion of a hierarchy}

Eva Hache's monologues do not mainly show a feminist, subversive humour (Holmes \& Marra 2002). Note that sequences aimed at hierarchy maintenance, establishment of women's in-group, and stereotype reinforcement amount to $77.62 \%$ of the total. Therefore, her monologues reinforce the status quo, showing stereotypes, and boundaries between sexes. However, some sequences $(22.36 \%$ of the total) may be classified as an attempt to change the status quo and co-construct other identities (Crawford 1995, 2003). This occurs when men are the butt of the jest, when she shows a non-stereotypical representation of sexes, or depicts an intersectional category (gay, lesbian, bisexual, etc.) (Day 2015: 21).

Our study has exemplified how masculine identity is depicted through teasing and mockery. As explained above, a man does not have his own voice, since he appears not as a speaker (locutor) but as an utterer. In example (13), Eva Hache speaks about men's underwear: 
(13)

Eva Hache: la ropa interior masculinaa

Público: RISAS

Eva Hache: da pena

Público: RISAS

(4")

Eva Hache: no $\downarrow$ y si no decidme cuánto tiempo hace que no decís ma-me voy a poner este panteste calzoncillo tan mono

Público: RISAS

Eva Hache: no/ no/ entre otras cosas como lo seguís comprando al peso como las ciruelas

Público: RISAS Y APLAUSOS (ECC, La Sexta, 30 de octubre de 2011).

Eva Hache: men's underwear

Audience: LAUGHTER

Eva Hache: it is pitiful

Audience: LAUGHTER

(4")

Eva Hache: no $\downarrow$ just tell me how long it is since you haven't said I'm going to wear these trousthese really beautiful underpants

Audience: LAUGHTER

Eva Hache: no/ no/ among other things/ since you still buy them by weight like plums

Audience: LAUGHTER AND APPLAUSE

It should be highlighted that humorous markers, such as kinesic elements (facial gestures) and pauses, play an important role in the building of the jab line in example (16). This is indicated by the loud laughter and applause coming from the audience. The use of the syntagmatic unit ropa interior [underwear] and the adverbial expression by weight form the jab line.

Even though most of the subversive sequences exhibit this type of humour, some sequences deal with other subversive topics. A topic related to women that is addressed differently is the menstrual period. Eva Hache uses one of its taboos -blood- to build the jab line of this sequence:

(14)

Eva Hache: la verdad que esto de los diseñadorees los diseñadores que diseñan para cosas que noque no conocen no pasa solo con la ropa deportiva ¿eh? hay casos aún más sangrantes y con sangrantes no me refiero al salvaslip con alas/ de braga tanga ${ }^{14}$

Público: RISAS Y APLAUSOS

(2")

Eva Hache: ¿EH? ss/ el traje de luces

Público: RISAS

Eva Hache: el que diseñó el traje de luces/ no ha visto un toro ni en Altamira

Público: RISAS

Eva Hache: vamos a ver $\rightarrow$ aqui tiene señor torero $\downarrow$ la mejor prenda para salir corriendo $\downarrow$ tú ¿con quién vas/ con el toro?

Público: RISAS

Eva Hache: ¡hombre por Dios!/ los pobres toreros no se visten/ los pobres toreros se envasan al vacío

Público: RISAS Y APLAUSOS (ECC, La Sexta, 4 de septiembre de 2011).

\footnotetext{
${ }^{14}$ She shakes her head.
} 
Eva Hache: the truth is this thing about designers $\downarrow$ the designers who design for things that they don't- that they don't know, it does not only happen with sportswear $\downarrow$ eh? there are even more gross cases and by gross $\downarrow$ I don't mean the panty-liners with wings/ for tanga panties

Audience: LAUGHTER AND APPLAUSE

(2')

Eva Hache: EH? ss/ the bullfighter's costume

Audience: LAUGHTER

Eva Hache: the person who designed the bullfighter's costume/ has never seen a bull $\downarrow$ not even in the Altamira caves

Audience: LAUGHTER

Eva Hache: let's see $\rightarrow$ here you are, Mr. bullfighter $\downarrow$ the best garment to run away $\downarrow$ you $\downarrow$ whose side are you on/ the bull's?

Audience: LAUGHTER

Eva Hache: boy $\downarrow$ for Christ's sake!/ poor bullfighters don't get dressed/ poor bullfighters vacuum pack themselves

Audience: LAUGHTER AND APPLAUSE

The use of sangrantes with both a literal meaning, related to the menstrual period, and a figurative one, linked to the collocation gross cases helps the monologist achieve a great success, this being one of her most applauded jab lines in the show that evening.

Finally, some humorous sequences represent an intersectional category - not a lot, however. Example (15) shows a jab line based on bicyclist, where the comedienne creates a humorous ambiguity based on two scripts: bisexual and bicycle rider:

(15)

Eva Hache: ¿eh? que igual parece que no $\downarrow$ pero para mí dar un paseo en bici ha sido la verdad una estupenda idea/ lo que no ha sido una buena idea ha sidoo hacerlo con mi amigo el biciclista Público: RISAS Y APLAUSOS

Eva Hache: ¿he dicho biciclista?

Público: RISAS Y APLAUSOS

Eva Hache: ¡ahi pues he dicho bien/ bi de bi[sexual y=]

Público:

[RISAS]

Eva Hache: =que le gusta la bici muchoo

Público: RISAS Y APLAUSOS (ECC, La Sexta, 8 de enero de 2012).

Eva Hache: eh? it may seem that it isn’t $\downarrow$ but $\downarrow$ for me/ going for a ride by bicycle was actually a wonderful idea/ however $\downarrow$ what was not a good idea was to do it with my friend the bicyclist

Audience: LAUGHTER AND APPLAUSE

Eva Hache: did I say bicyclist?

Audience: LAUGHTER AND APPLAUSE

Eva Hache: ah; well $\downarrow$ I said it properly/ bi from bi [sexual and=]

Audience: [LAUGHTER]

Eva Hache: $=$ that he likes cycling a lot

Audience: LAUGHTER AND APPLAUSE

The new lexical creation bicyclist is a humorous indicator based on the ambiguity that permits not only to infer a conventional meaning, related to bicycle rider but also to evoke the word bisexual thanks to the prefix $b i$-. Even though the incongruity is solved by the comedienne later ("bi from bisexual and that he likes cycling a lot"), the blended space encourages the audience to question the status quo (Bing \& Scheibman 2014: 29) and consequently to develop ways for a subversive humour. 


\section{Conclusion}

An attempt has been made in the previous sections to show how the comedienne's style reflects her feminine identity. As both the quantitative and qualitative analysis have shown, topics based on relationships are more frequent $(85.69 \%)$ than those associated with work (14.28\%), notwithstanding the fact that most of the former have to do specifically with sex (42.84\%). This prominence of the sex as a topic could be explained by the high representation of identity clash in humorous sequences $(27.63 \%)$. She also depicts the feminine identity's voice $(30.26 \%)$, usually confronting it with the masculine identity $(42.1 \%)$.

There were 76 humorous sequences identified in the corpus. As explained above, a humorous sequence consists in a discontinuous intervention, which is disrupted by laughter and audience applause. Humorous clues and indicators play a crucial role when building jab lines and punch lines. As the corpus shows, men are depicted as a stigmatised, targeted, and mocked gender. Instead of presenting a man as a speaker (locutor), he usually appears as an utterer, which increases the humorous effects and ensures success for these sequences amongst the audience.

As regards the effects of sequences, Eva Hache's humorous gendered monologues do not usually represent a subversive point of view (22.36\%), whereas hierarchy maintenance $(43.42 \%)$, stereotype reinforcement $(19.73 \%)$, and the establishment of women's in-group (14.47\%) jointly account for the highest percentage (77.62\%). Although subversive effects do not appear so strongly in our corpus, some pragmatic functions were identified, such as the mockery of men, the representation of a non-stereotypical gender identities, and the explanation of an intersectional category (gay, lesbian, bisexual, etc.). In general, the feminine identity is depicted as an instrument to maintain the status quo or to support an in-group. Despite the fact that feminine identity appears more frequently in the humorous sequences, sometimes the achieved effect is to strengthen stereotypes and differences between sexes. However, the masculine identity is also depicted as subversive humour from women's point of view; more precisely, criticism towards men serves as the foundation for this type of humour against gender normativity.

On the whole, Eva Hache's monologues do not primarily support a feminist and subversive humour, although these types of sequences could be understood as an attempt to subvert the status quo. It is frequent for a monologue in the corpus to open with a sequence that reinforces the status quo, and then, after a few minutes, Eva Hache creates a subversive sequence. This fact may explain the highest incidence of maintenance sequences as opposed to those focused on subversion. However, the prominence and success of subversive sequences should point to a new trend in stand-up monologues in Spain. Further research on the subversive sequences by other comediennes, who uphold a feminist kind of humour (RuizGurillo \& Linares-Bernabéu forthcoming), may broaden the scope of performing gender through humour in Spanish.

\section{Acknowledgements}

This research was supported by the Valencian Regional Department of Education, Research, Culture and Sport by means of the grant PROMETEO/2016/052 "Gender-based humour: Observatory of identity of women and men through humor"; and by the Spanish Ministry of Economy and Competitiveness by means of the grant FFI2015-64540-C2-1-P "Gender, humour and identity: Development, consolidation and applicability of linguistic mechanisms in Spanish" (MINECO-FEDER, UE). For further information, visit the webpage 
http://dfelg.ua.es/griale/. I would like to thank Esther Linares for her fruitful suggestions and revisions.

\section{References}

Attardo, S. 2001. Humorous Texts: A Semantic and Pragmatic Analysis. Berlin: Mouton de Gruyter.

Attardo, S. 2008. 'A primer for the linguistics of humour', in Raskin, V. (ed.), The Primer of Humor Research, Berlin: Mouton de Gruyter, pp. 101-155.

Bing, J. 2004. 'Is feminist humour an oxymoron?,' Women and Language 27(1), pp. 22-23.

Bing; J. \& Scheibman, J. 2014. 'Blended spaces as subversive feminist humour', in Chiaro, D. \& R. Baccolini (eds.), Gender and Humour. Interdisciplinary and International Perspectives, London: Routledge, pp. 13-29.

Briz, A. y grupo Val.Es.Co. 2002. Corpus de conversaciones coloquiales [Corpus of colloquial conversations]. Madrid: Arco/Libros.

Butler, J. 1993. Bodies that Matter. On the Discursive Limits of "Sex". New York: Routledge.

Chiaro, D. \& Bacolini, R. 2014. 'Humour: A many gendered thing', in Chiaro, D. \& R. Baccolini (eds.), Gender and Humour. Interdisciplinary and International Perspectives, London: Routledge, pp. 1-9.

Coates, J. 2014. 'Gender and humour in everyday conversation', in Chiaro, D. \& R. Baccolini (eds.), Gender and Humour. Interdisciplinary and International Perspectives, London: Routledge, pp. 147-164.

Crawford, M. \& Gressley, D. 1991. 'Creativity, caring, and context. Women's and men's account of humour preferences and practices.' Psychology of Women Quarterly 15, pp. 217-231.

Crawford, M. 1995. Talking Difference. On Gender and Language. London: Sage.

Crawford, M. 2003. 'Gender and humour in social context.' Journal of Pragmatics 35, pp. $1413-1430$.

Day, A. 2015. 'Pretty/funny: Women comedians and body politics. Review of Mizejewski. L. 2014. Pretty/Funny: Women Comedians and Body Politics. Austin: University of Texas Press.' Feminist review 111, pp. 21-22.

Ducrot, O. 1996. Slovenian Lectures/Conferences Slovènes. Ljubljana: ISH.

Greenbaum, A. 1999. 'Stand-up comedy as rhetorical argument: An investigation of comic culture.' Humour: International Journal of Humour Research 12-1, pp. 33-46.

Grupo Val.Es.Co. 2014. 'Las unidades del discurso oral. La propuesta Val.Es.Co. de segmentación de la conversación (coloquial)' [The oral discourse units. Va.Es.Co proposal on conversation (colloquial) segmentation]. Estudios de lingüística del español [Studies of Spanish Linguistics], 35, pp. 11-71.

Hay, J. 2000. 'Functions of humour in the conversations of men and women.' Journal of Pragmatics 32, pp. 709-742.

Holmes, J. \& Marra, M. 2002. 'Having a laugh at work: How humour contributes to workplace culture.' Journal of Pragmatics 34, pp. 1683-1710.

Holmes, J., M. Marra \& L. Burns. 2001. 'Women's humour in the workplace: A quantitative analysis.' Australian Journal of Communication 28, 1, pp. 83-108.

Holmes, J. \& Meyerhoff, M. (eds). 2003. The Handbook of Language and Gender. Oxford: Blackwell.

Kotthoff, H. 2006. 'Gender and humour: The state of art.' Journal of Pragmatics, 38, pp. 4-25. 
Lampert, M. \& Ervin-Tripp, S. M. 1998. 'Exploring paradigms: The study of gender and sense of humour near the end of the $20^{\text {th }}$ century', in Ruch, W. (ed.), The Sense of Humour: Explorations of a Personality Characteristic, Berlin: Mouton de Gruyter, pp. 231-270.

Litosseliti, L. \& Suderland, J. (eds.) 2012. Gender Identity and Discourse Analysis. Amsterdam: John Benjamins.

Lockyer, S. 2011. 'From toothpick legs to dropping vaginas: Gender and sexuality in Joan Rivers' stand-up comedy performance'. Comedy Studies, 2(2), pp. 113-123.

Martin, R. A. 2014. 'Humour and gender: An overview of psychological research', in Chiaro, D. \& R. Baccolini (eds.), Gender and Humour. Interdisciplinary and International Perspectives, London: Routledge, pp. 123-146.

Mushtaq, S. A. 2017. 'Humour: As a tool for gender construction and deconstruction.' International Journal for Intersectional Feminist Studies, 3 (1), pp. 29-38.

Pons, S. 2014. 'Models of discourse segmentation in Romance languages,' in Pons, S. (ed.), Discourse Segmentation in Romance Languages, Amsterdam: John Benjamins, pp. 1-21.

Raskin, V. 1985. Semantic Mechanisms of Humour. Dordrecht: D. Reidel.

Rozek, C. 2015. 'The gender divide in humour: How people rate the competence, influence, and funniness of men and women by the jokes they tell and how they tell them.' Honours Thesis Collection. Paper 296.

Ruiz-Gurillo, L. 2012. La lingüistica del humor en español [Linguistics of humour in Spanish]. Madrid: Arco/Libros.

Ruiz-Gurillo, L. 2013a. 'Narrative strategies in Buenafuente's humorous monologues.' In Ruiz-Gurillo, L. \& M M B. Alvarado Ortega (eds.), Irony and Humour: From Pragmatics to Discourse, Amsterdam: John Benjamins, pp. 107-140.

Ruiz-Gurillo, L. 2013b. 'Eva Hache y El Club de la Comedia: del guión monológico al registro dialógico' [Eva Hache and El Club de la Comedia: from the monologic script to the dialogic register]. Onomázein, 28, pp. 148-161.

Ruiz-Gurillo, L. 2014. 'Infiriendo el humor. Un modelo de análisis para el español.' [Inferring humour. An analysis model for Spanish]. CLAC, 59, pp. 148-162.

Ruiz-Gurillo, L. 2015a. 'Phraseology for humour in Spanish: Types, functions and discourses.' Lingvisticae Investigationes 38(2), pp. 191-212.

Ruiz-Gurillo, L. 2015b. 'Sobre humor, identidad y estilos discursivos: los monólogos de Eva Hache.' [On humour, identity and discursive styles: Eva Hache's monologues]. Tonos Digital 28.

Ruiz-Gurillo, L. 2016. 'Metapragmatics of humour: Variability, negotiability and adaptability in humorous monologues', in Ruiz-Gurillo, L. (ed.), Metapragmatics of Humour: Current Research Trends, Amsterdam: John Benjamins, pp. 81-104.

Ruiz-Gurillo, L. \& E. Linares-Bernabéu. Forthcoming. 'Subversive Humor in stand-up comedy: Two case studies in Spanish'. Humour: International Journal of Humour Research.

Rutter, J. 2001. 'Rhetoric in stand-up comedy: Exploring performer-audience interaction'. Stylistyka 10, pp. 307-325.

Shilikhina, K. 2017. 'Metapragmatic markers of the bona fide and non-bona fide modes of communication', in Chlopicki, W. \& D. Brzozowska (eds.), Humorous Discourse, Amsterdam: Mouton de Gruyter, pp. 107-130.

Timofeeva, L. 2012. El significado fraseológico. En torno a un modelo explicativo y aplicado [The phraseological meaning. On an explanatory and applied model]. Madrid: Ediciones Liceus.

Van Dijk, T. A. 1995. 'Discourse semantics and ideology.' Discourse \& Society, 6(2), pp. 243-289.

Yus, F. 2016. Humour and Relevance. Amsterdam: John Benjamins. 